\title{
O Ensaio sobre a Música Brasileira: Estudo dos Matizes Ideológicos do Vocabulário Social e Técnico-Estético (Mário de Andrade, 1928)
}

\author{
Arnaldo Daraya Contier
}

"Deuses e homens - os galeados escudeiros - dormiram toda a noite. Somente Zeus não se deixou vencer pelo profundo sono... (Homero, Iliada)

"... a feiçam deles he seerem pardos maneira davermelhados de boõs rrostos e boõs narizes bem feitos." (Carta de Pero Vaz de Caminha do descobrimento da terra nova que fez Pedro Álvares Cabral ao El Rey nosso Senhor. 1 de maio de 1500)

"Subi pelo tronco, Desci pelo gaio;

Viva a Lei Treze de Maio (bis)"

(Samba, São Paulo.

Mário de Andrade, O Ensaio..., 1928)

\section{Entre Homero e Cabral}

Durante a década de 1920, o debate sobre o "nacional" e o "popular" na música erudita brasileira aflorou nos diversos ensaios, artigos, livros escritos por Mário de Andrade, Luciano Gallet, Lorenzo Fernandez, Ronald de Carvalho, Heitor Villa-Lobos, Renato Almeida, Graça Aranha, Fabiano Lozano, Sérgio Milliet, entre outros ${ }^{1}$. Consciente ou inconscientemente, esses intelectuais 
respiraram a "agitação nacionalista" de matizes político-culturais diversos, num primeiro momento nos ensaios publicados pela $R e-$ vista do Brasil (1916-24): “... sua feição geral se manteve no plano cultural, salientando a necessidade de se buscar a identidade nacional e o problema da unidade"2, e num segundo, no fim do decênio, pelos artigos produzidos pelas facções do movimento modernista que começaram reivindicar mudanças sociais, políticas, culturais, institucionais, atribuindo menor ênfase à forma e, paralelamente, privilegiando o conteúdo. Os fins dos anos 20 caracterizaram-se como uma fase "... mais socialmente orientada, assim como de maior influência recíproca entre o nacionalismo intelectual e o político, que ocorreria na década de 1930"3.

No Ensaio sobre a música brasileira, Mário de Andrade, em 1928, utilizou um vocabulário técnico-estético e ideologicamente marcado por uma determinada interpretação da História do Brasil. Naquela obra, Mário realizou um estudo amplo e genérico sobre possíveis relações entre as músicas popular e erudita, almejando envolver emotivamente o jovem artista (compositor ou intérprete) no seu projeto em prol da nacionalização da música erudita brasileira.

Para Mário, a Nação brasileira era considerada atrasada, sob os pontos de vista: econômico, social, político, cultural e filosófico. Apesar de criticar o atraso, a falta de tradição cultural e a "ignorância" estética da burguesia da. Belle Époque, Mário assumiu no Ensaio, em alguns de seus trechos, uma visão "otimista" em face do futuro, exaltando o "progresso" como algo natural e inconscientemente internalizado no homem, capaz de voltar-se para as suas "raízes", contribuindo para a "libertação" do Brasil em face do seu passado musical visto como "decadente", em especial durante o período de 1889 a 1918. Mário esboçou no Ensaio uma pregação missionário-doutrinária, visando despertar nos artistas uma tomada de consciência de seus "erros", tais como: exotismo; individualismo exacerbado; mimetismo; apologia do tradicionalismo musical europeu. O debate sobre o nacionalismo e identidade cultural no campo não-musical foi amplamente discutido por Monteiro Lobato ${ }^{4}$; pelo grupo da Antropofagias; pelo movimento Verde- 
Amarelo ou "Anta"; pelos ensaístas Paulo Prado, Alberto Torres, entre outros ${ }^{7}$. A identidade cultural cristalizou-se na música sem divergências teóricas nos trabalhos de: Mário de Andrade, Luiz Heitor Corrêa de Azevedo, Andrade Muricy, Arnaldo Estrela, Renato Almeida, Antônio Sá Pereira, Eurico Nogueira França.

Nos textos publicados pós-1928, os signos musicais foram explicitados pelos modernistas nacionalistas, sob argumentos de colorações ideológicas muito semelhantes: “... faz muitos anos que, escutando amorosamente o despontar da consciência nacional, cheguei à conclusão de que si esta alguma vez já se manifestou com eficiência na arte, unicamente o fez pela música (...) o querer ser universal desraçadamente é uma utopia (...) Nós temos hoje inegavelmente uma música nacional. Mas esta ainda se conserva no domínio do povo, anônima. Dois homens porém tornaram-se notáveis na construção dela: Ernesto Nazareth e Marcelo Tupinambá. São, com efeito, os músicos brasileiros por excelência...".

Antônio Cândido analisou dialeticamente o movimento modernista: "... no terreno social e político, o país atrasado e novo precisa ser nacionalista, no sentido de preservar e defender a sua autonomia e a sua iniciativa; mas, no terreno cultural, precisa receber incessantemente as contribuições de países ricos, que economicamente o dominam. Daí uma dialética extremamente comple$x a$, que os modernistas brasileiros sentiram e procuraram resolver ao seu modo. É fundamental todo o seu movimento de valorização dos temas nacionais, a consciência da mestiçagem, a reabilitação dos grupos de valores marginalizados (índio, negro, proletário). Mas, curiosamente, fizeram isso recorrendo aos instrumentos libertadores da vanguarda européia, isto é, dos países de cujo império cultural procuravam ao mesmo tempo se livrar"'.

No campo musical, o debate sobre o "nacional" e o "popular", instaurado pelos modernistas, prendeu-se, de um lado, pela "eficiência na arte" manifestada in totum na música ("som + raça"), e, de outro, pelo movimento de vanguarda ocorrido em diversos pólos culturais europeus, de matizes exclusiva e marcadamente nacionalistas. Esse movimento modernista baseou-se, de um lado, 
na descoberta das "falas culturais" do "povo inculto" (folclore "puro" ou nos traços de brasilidade internalizados em algumas obras escritas pelos compositores urbanos, tais como: Marcelo Tupinambá, Chiquinha Gonzaga, Ernesto Nazareth, e, de outro, em algumas músicas escritas por Manuel de Falla (Espanha, 18761946) - cores impressionistas, folclore andaluz; Hanns Pfitzner (Alemanha, 1869-1949) - três óperas inspiradas no wagnerianismo, estética conservadora após a ascensão de Hitler em 1933; Ralph Vaughan (Inglaterra, 1972-1958); Karol Szymanowski (Polônia, 1882-1937, Stabat Mater, essencialmente de colorações nacionalistas; Béla Bartók (Hungria, 1881-1945) - músicas inspiradas nas canções populares, ultrapassando o sistema Maior/menor, descobrindo novos ritmos, melodias, timbres; Igor Strawinsky (18821971) - período russo até 1920, inspirou-se no folclore e na tradição russos; Darius Milhaud (França, 1892-1974) - escreveu 443 obras impregnadas de politonalidade, foi influenciado pelo folclore brasileiro, norte-americano (jazz), da região da Provença e judaico; Zoltan Kodály (Hungria, 1882-1967) - pesquisas dos cantos populares -, entre outros.

Na música, a dicotomia "nacional"/universal fundamentou-se no nacionalismo como o ponto nodal da fase de construção de um imaginário erudito brasileiro sintonizado com o atraso econômico, político, filosófico do País e com as vanguardas nacionalistas européias (Bartók, Strawinsky, Milhaud).

Esse imaginário, inspirado na música folclórica, simbolizou para os intelectuais - liberais, integralistas, socialistas, fascistas (período de 1928 a 1960) - um contradiscurso revolucionário, visando combater, com virulência, o gosto musical das elites burguesas do Rio de Janeiro e São Paulo, ainda "prisioneiras" do gosto artístico herdado da Belle Époque. E, além disso, fortemente influenciadas pelos ideais de "civilização", de "progresso", tentando aproximar o Brasil de uma "Europa possível".

Essas elites burguesas ora aplaudiam as músicas escritas por Frédéric Chopin, Ludwig van Beethoven; as operetas, por J. Offenbach; óperas, por G. Verdi, G. Rossini, Meyerbeer; ora repu- 
diavam, com veemência, músicas brasileiras cujos ritmos lembravam o chamado "atraso": "Brasil-Colônia"; o negro, como símbolo de um "povo infantil"; danças "obscenas", como os maxixes, sambas, os "embalos" dionisíacos do Carnaval popular, visto como símbolo da licenciosidade ou do paganismo; epidemias de varíola ou da febre tifóide...

O discurso sobre a música nacionalista erudita brasileira aflorou no Brasil através de um vocabulário "agressivo", "virulento", "dogmático", "autoritário", visando combater a "presença", nos anos 20 e 30, de traços culturais herdados da Belle Époque: "... nada expressa melhor a belle époque carioca do que a nova Avenida Central - um imenso bulevar cortando as construções coloniais da Cidade Velha (...). O empreendimento foi considerado miraculoso tanto por sua rapidez quanto pela comoção pública que causou. Em um ano e meio, foram destruídas cerca de 590 edificações da Cidade Velha (...). Frontin, por exemplo, assegurou que a avenida se transformasse em uma vitrine da Civilização..."10.

As influências francesas tornaram-se mais visíveis no Teatro Municipal do Rio de Janeiro. A Avenida Central era considerada o principal símbolo ou metáfora da reforma urbanística, pois representava, para as elites neodarwinistas, os ideais de Civilização e de Progresso do Brasil Republicano. As reformas empreendidas pelo prefeito Pereira Passos, sob o governo de Rodrigues Alves (190206), simbolizaram, concomitantemente, os temas centrais dos discursos da elite política e cultural carioca: "recusa e evasão" ${ }^{11}$. Ou seja, a elite enaltecia as novas obras e, paralelamente, criticava, com virulência, tudo o que era "desfeito" ou "destruído" como algo próximo às suas concepções sobre o "atraso" (Brasil agrário e escravocrata).

Essas elites enalteceram a tomada de medidas práticas - destruições dos cortiços da Cidade Velha, por exemplo - e compartilharam com as "mudanças simbólicas (...) vale a pena notar, por exemplo, as batalhas de flores no Campo de Santana reformado, ativamente promovidas pelo presidente e pelo prefeito, ou lembrar as solenidades relativas ao 'milagre' da Avenida Central - os novos signos da Civiliza- 
ção da cidade foram eficientemente manipulados de modo a causar o maior impacto possível sobre os contemporâneos"12.

Devido às especificidades históricas, a elite carioca da Belle Époque pretendeu "apagar" da memória o passado colonial e "exterminar" todos os vestígios raciais (ex-escravos; a ociosidade dos tocadores de violão ou os dançarinos de maxixes), que eram vistos como a herança do "passado" ainda "presente" na cidade pós-reformas empreendidas por Pereira Passos. Os ideólogos da reforma urbanística condenavam as ruas estreitas e imundas, "... mas também as fachadas sem pintura, os estilos rurais de consumo e os aspectos 'bárbaros' do Carnaval". A elite sentia-se "envergonhada" com os entrudos, cordões, o Carnaval, vistos como símbolos da cultura afro-brasileira e que negavam a Avenida Central como a metáfora da Civilização: "Paris como a capital da modernidade". Olavo Bilac atacou raivosamente os abomináveis cordões, "que lembravam as bacanais do Império Romano..."

"Tais indivíduos queriam pôr fim ao Brasil antigo, ao Brasil 'africano' que ameaçava suas pretensões à Civilização, apesar de se tratar de uma África bem familiar à elite (...). Uma parcela substancial da população da cidade, talvez mais da metade, compunhase de descendentes de africanos, e suas tradições se mesclavam e floresciam nas áreas mais pobres da Cidade Velha e nos morros. $\mathrm{Na}$ verdade, as favelas, conjuntos de barracos amontoados nos morros, haviam sido erguidas perto da nova área de docas ao norte, no final do século XIX, e foi para lá que se dirigiram muitos desabrigados das habitações decadentes da Cidade Velha, demolidas com as reformas de 1903-6"13. Os excluídos sociais (chorões, sambistas, por exemplo) do Rio de Janeiro, após essa reforma urbanística, foram expulsos para os subúrbios ou para os morros (favelas). As perseguições de policiais em face da "presença" dos homens pobres, descalços ou mal-vestidos na Avenida Central e na Rua do Ouvidor durante as décadas de 1910 e 20, visavam transformar esses espaços geográficos da Cidade em "lugares" a serem freqüentados pelos homens brancos das elites burguesas dominantes. Entretanto, essas elites não conseguiram "destruir" o imaginá- 
rio musical praticado pelos chorões - músicos populares -, que passaram a freqüentar todos os espaços e lugares da memória: cinemas, cabarés, dancings, cafés da Cidade Nova. E, assim, os maxixes, tangos, choros "invadiram" esse "universo higiênico" e civilizado!!!

A "presença" desses artistas pobres nos diversos teatros de revista da Lapa ou da Praça Tiradentes favoreceu a divulgação de centenas e centenas de maxixes, sambas, tangos, valsas escocesas, polcas. E, paradoxalmente, alguns artistas das classes médias e das elites passaram a "escutar" com interesse esses "novos sons", que colocaram em xeque o universo musical da Belle Époque. Paulatinamente, Heitor Villa-Lobos, Alberto Nepomuceno, Luciano Gallet, Darius Milhaud, Mário de Andrade, Renato Almeida, Graça Aranha, Oswald de Andrade, Ronald de Carvalho, Arthur Rubinstein, Vera Janacopulos, entre outros, começaram a descobrir esse "Brasil Novo" fortemente ligado às práticas artísticas do "povo".

A descoberta desse Brasil pelos intelectuais e apresentado pela música popular motivou a formação de uma verdadeira Cruzada em prol da pesquisa desse imaginário cultural. Em São Paulo, com a proclamação da República, os Donos do Poder elaboravam um projeto visando transformar os homens pobres em trabalhadores a serviço do capital. Esses ideólogos perceberam que esse projeto não poderia ser direcionado para uma transformação do homem pobre num trabalhador, sob o ponto de vista econômico, mas que esse projeto deveria voltar-se para modificar "espiritualmente" esses homens, almejando induzi-los a aceitar uma ética do trabalho: “... a constituição do mercado de trabalho requeria a montagem de uma rede de instituições de vigilância sistemática e controle dos trabalhadores não só nos ambientes de trabalho, mas, também, na sua vida cotidiana, adentrando por sua casa, esquadrinhando suas relações familiares e seus momentos de lazer (...) A cidade tornouse, assim, objeto privilegiado ou mesmo exclusivo da intervenção médica, pois, ao expressar-se na visão dos poderes constituídos como um ambiente de 'desordem', propiciava a propagação de doenças, não só as físicas, mas também sociais e morais"14. 
Mário de Andrade vivenciou esse momento histórico marcado pelo conservadorismo das elites, que visavam "exterminar" ou "silenciar" as práticas culturais dos "homens pobres". Por essa razão, num texto escrito em 1921, admitiu que a "música brasileira existia exclusivamente na canção popular"'15. E acrescentava: a música folclórica ou popular, "rica" em temas, ritmos, formas, timbres ainda não havia passado da " ... boca dos rapsodos andantes para a eternização dum Homero que a genializasse"16.

Nos inícios dos anos 20, Mário criticou, "ácida" e "duramente", a falta de "patriotismo" dos compositores e intérpretes que incluíam peças de autores estrangeiros em seus repertórios, como por exemplo, o Hino Nacional de Gottschalk ${ }^{17}$. Apesar dessas críticas às elites artístícas, Mário demonstrou um certo otimismo em face dos "artistas jovens": “... esperemos de Villa-Lobos, Guiomar Noyaes, Lúcia Branco, Pagliucci, Francisco Mignone um possível interesse no sentido de abraçar o programa modernista". Devido a essa conjuntura histórica, Mário afirmou inconsciente e categoricamente no Correio Musical Brasileiro, em julho de 1921: “... por enquanto a música brasileira não existe..."18. Nessa ocasião, procurou denunciar a existência e o desinteresse dos intelectuais brasileiros pelos estudos sobre a realidade histórico-cultural do "povo inculto". Ou seja, a sua "fala", de matizes "agressivos", opunha-se ao imaginário conservador das elites burguesas dos inícios do século. E, para solucionar esse impasse, defendeu a instauração de um sistema educacional capaz de incutir nos alunos um interesse pela pesquisa sobre temas da cultura brasileira.

No decênio de 1930, “... ocorreu um fato que esclarece os mecanismos do nosso nacionalismo cultural: a fundação das escolas superiores de estudos sociais, filosóficos e literários. E de universidades que não fossem simples soma de escolas preexistentes, mas correspondessem a um projeto orgânico de instauração do saber por meio da reflexão e da investigação desinteressadas, isto é, não vinculadas imediatamente às exigências da formação profissional. Foi o que começou a ser realidade em São Paulo, a partir de 1933 e 1934. (...) Enquanto os mestres franceses nos obrigavam a 
olhar o mundo circundante, recorrer às fontes locais, descobrir documentos, investigar a realidade próxima, os brasileiros, patriotas e oradores de 7 de setembro, acabavam por nos tirar do Brasil e nos iniciarem num mundo inexistente. Os franceses, usando a sua língua, empregando os seus métodos, nos punham dentro do país. Mas eram combatidos pelos nacionalistas do tipo patrioteiro como elementos 'alienígenas', que vinham conspurcar a visão correta (isto é, fantástica) do país..."19. Entretanto, no campo da pesquisa do folclore musical, tornou-se dificil "separar" com nitidez os documentos arrolados por Basílio de Magalhães, Renato Almeida, Heitor Villa-Lobos ou Mário de Andrade, e as suas "interpretações" pelos chamados intelectuais "patrioteiros". Em geral, os folcloristas brasileiros aceitaram "com reservas" os trabalhos dos sociólogos e antropólogos, tais como os ensaios escritos por Roger Bastide, Florestan Fernandes ${ }^{20}$ ou Maria Isaura Pereira de Queiroz.

Essa postura de Mário sobre a inexistência de uma música erudita brasileira, em 1921, não colocou em xeque a produção artística de alguns compositores do século XIX e dos inícios do século XX, tais como: José Maurício Nunes Garcia, Francisco Manuel da Silva, Antônio Carlos Gomes, Alberto Nepomuceno, Alexandre Levy. Apenas procurou "alertar" os jovens artistas sobre os novos tempos aflorados pós-Primeira Guerra Mundial (1914-18) e marcados, fundamentalmente, pela nacionalização das artes conforme técnicas defendidas pelos modernistas brasileiros e estrangeiros sintonizados com o mesmo "programa", tais como: Béla Bartók, Kodály, Darius Milhaud, Igor Strawinsky, César Cui, Manuel de Falla. Entretanto, o "nacional" na música brasileira já vinha sendo internalizado, consciente ou inconscientemente, nas obras popular e urbana de centenas e centenas de artistas, em sua maioria homens pobres ou excluídos sociais, a partir dos fins do século XIX. As escutas de algumas dessas músicas tornaram-se fontes de "inspiração" de obras divulgadas nos teatros de revista, nos saguões dos cinemas, nos cabarés, nas gafieiras, como por exemplo, Chiquinha Gonzaga, Ernesto Nazareth, Marcelo Tupinambá, Catulo da Paixão Cearense, Pixinguinha, Donga, Anacleto de Medeiros ${ }^{21}$. 
Alguns maxixes, choros, tangos brasileiros escritos pelos compositores populares ou "semi-eruditos" foram elogiados pelos intelectuais brasileiros, ou não, e envolvidos pelo "modernismo nacionalista", tais como: Darius Milhaud, Arthur Rubinstein, Mário de Andrade, Vera Janacopulos, Renato Almeida ${ }^{22}$, Oswald de Andrade, Graça Aranha.

Em 1921, Mário, alertando os artistas sobre a inexistência da música brasileira erudita, preconizava o aparecimento de um Homero capaz de "inspirar-se" nas "falas culturais" do povo ou dos rapsodos. Em alguns de seus artigos publicados entre $1922 \mathrm{e}$ 1928, Villa-Lobos foi reconhecido como esse "homem novo"Homero - que, em função de sua "genialidade", havia conseguido "decifrar" e "internalizar" nos seus choros, por exemplo, alguns traços sonoros inspirados nos cantadores anônimos.

Mário de Andrade formou-se em piano e canto pelo Conservatório Dramático e Musical de São Paulo em 1917. Exerceu, nesta Escola, a função de professor de História da Música, Folclore, entre outras disciplinas, durante muitos anos. Como poeta e crítico musical escreveu inúmeros artigos publicados nos principais periódicos do País no período de 1919 a $1945^{23}$. Em alguns desses textos, Mário, implícita ou explicitamente, indicou possíveis "caminhos" a serem percorridos pelos artistas interessados na construção de um projeto em prol da nacionalização da música erudita brasileira. Paulatinamente, os seus "conselhos" - ora raivosos, irônicos, paternalistas, otimistas; ora dogmáticos, doutrinários, autoritários - polarizaram o debate sobre o modernismo musical durante muitas décadas entre compositores, professores, intérpretes.

Os argumentos de Mário, ora de traços iluministas, ora imbuídos de ideais românticos, mantiveram-se presos em torno do tema sobre a "nacionalização" da música brasileira no período de 1921 a 1945. Com a verbalização do seu projeto sobre o "nacional" e o "popular" na música erudita, Mário procurou "identificar" nas obras de autores brasileiros (popularescos ou eruditos) ${ }^{24}$ traços que se harmonizassem com as suas "escutas" rigorosamente direcionadas na busca de uma determinada concepção de brasilidade. Por essa 
razão, nos seus artigos sobre a música brasileira, ora elogiava ou exaltava obras escritas pelos compositores considerados como os "mais puros representantes da modernidade - "... não sei de quem melhor componha canções atualmente no Brasil [1940]. Pela fôrça expressiva, pela completa assimilação erudita dos elementos característicos populares, pela originalidade da polifonia acompanhante e a beleza das melodias, as canções de Camargo Guarnieri, são a sua melhor contribuição para a música brasileira. Agora teremos que seguir a entrada em plena maturidade de um artista que desde muito deixou de ser apenas uma promessa, e se tornou uma das fôrças mais vivas e profundas da música nacional contemporânea"25 -, ora criticava, com virulência, autores consagrados que haviam abandonado o projeto modernista em busca de um "aplauso fácil": em fevereiro de 1939, criticou uma peça escrita por Heitor VillaI_obos para sincronizar filmes sobre o Brasil a serem apresentados durante a Feira Mundial de Nova Iorque: “... dentre os compositores vivos, o maior de todos, Villa-Lobos, está fracamente representado. Mas aqui a culpa cabe exclusivamente ao compositor, que deu para gravar uma espécie de exotismo musical que compôs recentemente, uma Melodia Moura. Trata-se de uma peça de escasso valor, espécie de rapsódia de todos os lugares comuns do arabismo musical do século passado"26. No caso de artistas considerados altamente significativos e muito elogiados pelos críticos nacionais ou internacionais, o autor de Macunaima, para "atenuar" as suas críticas sobre a Melodia Moura, terminou o seu artigo utilizando uma oração adversativa: “... mas sempre é certo que o autor dos choros, reservou para si próprio a gravação das suas admiráveis Bachianas, de que já dei notícia por este jornal. Como estão gravadas não sei, que não as ouvi"27.

\section{Entre Mulher Rendeira e os Choros $n^{\circ} 10$ de Villa-Lobos}

As "escutas" do cancioneiro popular - coros, sambas, emboladas, frevos - e de algumas músicas escritas por Chiquinha Gonzaga, 
Ernesto Nazareth, Marcelo Tupinambá, Heitor Villa-Lobos "influenciaram", consciente ou inconscientemente, a redação d'O Ensaio sobre a música brasileira por Mário de Andrade, em 1928.

O Ensaio ou Manifesto caracterizou-se, em linhas gerais, pelo seu conteúdo programático polêmico e doutrinário-dogmático. Devido à sua natureza - de matizes marcadamente ensaísticos apresenta uma fundamentação teórica (técnica e estética) muito genérica e pouco rigorosa: “... existe, na exposição do autor do Ensaio, uma visível confusão conceitual entre síncopa e contratempo, entre ritmo e rítmica (...) A síncopa é dita de formação inconsciente. Está claro que não é - a menos que aqui se deva admitir como sinônimo de inconsciência a sedimentação pelo uso (...) em nenhum momento há avanços na direção de uma análise musical..."28.

O Ensaio - ou a "Bíblia" dos compositores nacionalistas brasileiros - foi lido, debatido, citado exclusivamente através de fragmentos, ora de colorações ideológicas, ora de matizes técnico-estéticos, por Camargo Guarnieri, Andrade Muricy, Luiz Heitor Correio de Azevedo, Francisco Mignone, Waldemar Mesquita, Osvaldo Lacerda, Vinicius de Moraes, Tom Jobim, entre outros compositores populares e eruditos, folcloristas, historiadores, críticos, intérpretes, professores, sociólogos, antropólogos, filósofos, políticos (integralistas, socialistas, fascistas, liberais, stalinistas).

Por que o Ensaio ocupou o centro dessa "roda viva" durante algumas décadas? Em função das idéias de brasilidade e de identidade cultural de um lado, e, de outro, em função do uso de uma linguagem emotiva envolvendo o artista brasileiro, profundo conhecedor, ou não, de técnicas de composição numa fase primitiva ou de construção: "... todo artista brasileiro que no momento atual fizer arte brasileira é um ser eficiente com valor humano. O que fizer arte internacional ou estrangeira, si não for gênio, é um inútil, um nulo. E é uma reverendíssima besta" ${ }^{29}$. E essa frase tornou-se o lema ou a bandeira de todo artista erudito ou popular preocupado com a internalização das chamadas "raízes" na música brasileira "autêntica". 
As tentativas de Mário, no sentido de conciliar esse projeto em prol da nacionalização da música brasileira e os traços técnicomelódicos, rítmicos, polifônicos, formais "inspirados" nos cantos folclóricos, esbarraram na inexistência de tratados teóricos mais rigorosos, semelhantes às propostas de um Béla Bartók sobre a pesquisa do imaginário popular ${ }^{30}$ e nas dificuldades de os compositores "captarem" e resolverem todos os impasses teóricos fundamentados nas obras escritas por J. P. Rameau, M. Moussorgsky, Claude Debussy, Arnold Schoenberg.

Essas teorias foram transmitidas pelos professores de composição e regência no Brasil para os seus alunos ${ }^{31}$. Estes tentaram conciliar essas teorias formuladas pelos autores europeus com as "especificidades técnicas" dos cantos populares brasileiros.

Num artigo de Mário, divulgado em 1930, essa questão foi retomada como "um pedregulho na botina" do compositor modernista: “...O prof. Sá Pereira que é músico sério (...) levantou (...) um problema de grande importância para nós: o da fixação duma terminologia musical brasileira. Um indivíduo pode falar errado todos os termos musicais que emprega e fazer música boa. Mas a fixação duma terminologia técnica nacional tem importância enorme, principalmente em países que nem o nosso, onde a importação de indivíduos profissionais é feita, em larga escala. Porquê palavras fixas e nossas se tornarão mais um obstáculo à estrangeirização que esses profissionais importados, consciente ou inconscientemente trazem consigo (...). Acho mesmo que não seria impossível, realizarmos um congresso, composto de músicos e conhecedores profundos da nossa fala, para a organização de um vocabulário musical" ${ }^{\prime 32}$.

Mário, envolvido com o ideal coletivista na música, não consegue enfrentar esta questão com rigor teórico: “... a técnica é um acervo individual (...) A técnica adquirida é a somatória que possibilita o edificar de uma composição musical. A técnica pressupõe uma certa disciplina. Arnold Schoenberg observa: 'não se trabalhando firmemente e da melhor maneira possível, não dará o Senhor a sua bênção' (...). Técnica é o material aprendido, estilo é a maneira de se expressar, após técnica assimilada. Ambos inexistem 
se não houver a idéia, esta intermediação necessária sem a qual não haveria estilo. Segundo Schoenberg, 'as idéias invadem a mente de maneira tão imprevisível e, por vezes, tão indesejada, como um som musical nos chega aos ouvidos ou um odor ao nariz" $"$ ".

Historicamente, o Ensaio criticava, de um lado, o "descaso" do governo republicano em face de um possível apoio financeiro almejando patrocinar e divulgar a música brasileira modernista erudita nos principais teatros do País; e, de outro, os intérpretes tradicionalistas contratados pelos empresários que almejavam a obtenção de lucros financeiros, patrocinando espetáculos operísticos ou sinfônicos visando atender ao gosto da chamada elite "ignara" da Belle Époque...

No Ensaio, Mário procurou, na primeira parte, indicar normas e critérios metodológicos sobre a importância do "aproveitamento" da música popular pelos artistas eruditos, e, na segunda, documentar cento e quarenta canções folclóricas, aproximadamente, divididas em dois grandes grupos: $\left.1 .^{\circ}\right)$ música socializada - canto infantil; cantos de trabalho; danças; danças dramáticas; cantos religiosos; cantigas militares; cantigas de bebida; coros; $2^{\circ}{ }^{\circ}$ ) Música individual; estribilhos (solistas ou corais); toadas; martelos, desafios, chulas, lundus e modinhas; pregões.

Com a "efervescência" nacional-populista intensificada às vésperas do Golpe de 1930, o Ensaio foi considerado um discurso altamente revolucionário em função da ênfase dada por Mário em torno da criação de uma arte musical de matizes nacionalistas. Paradoxalmente, o discurso musical visto pelos formalistas como assemântico, enigmático, polissêmico, anti-ideológico, tornou-se o ponto nodal das obras, artigos, projetos escritos por: Lorenzo Fernandez, Oswald de Andrade, Graça Aranha, Luciano Gallet, Camargo Guarnieri, Cassiano Ricardo, Custódio Mesquita, Bidu Sayão, Antônio de Sá Pereira, Heitor Villa-Lobos, Monteiro Lobato, Paulo Figueiredo, Anísio Teixeira, Getúlio Vargas, entre outros.

Por que? A música tornou-se o símbolo da "alma brasileira", da Pátria e da Nação. 
Antônio de Sá Pereira, co-autor de um projeto de reforma curricular da Escola Nacional de Música em 1930-31, juntamente com Luciano Gallet e Mário de Andrade, e nos anos 30 um dos ardorosos defensores de um programa em prol da nacionalização da dramaturgia teatral no Brasil, assim se manifestou, em 1943, sobre o Ensaio: “... de idéia como o pólen, lançado aos quatro ventos, Mário de Andrade fecundou o pensamento de toda uma geração. Na poesia, na literatura, na pintura, na escultura, nos estudos folclóricos e sociológicos, e na música, eu creio não existir artista brasileiro, dos últimos 20 anos que, caminhando pela sua estrada, não tenha topado com as pegadas desse gigante que, antes dele, já por ali passara..."34.

Para o diplomata e historiador da música brasileira Vasco Mariz, o Ensaio representou uma "obra de independência que empolgou e arrastou a mocidade musical da época desejada pelo autor..." 35

No período de 1928 a 1970, aproximadamente, alguns "herdeiros" e simpatizantes das "teses" de Mário sobre a música brasileira, consideram-no como o Segundo Descobridor do Brasil. Para o crítico Andrade Muricy, por exemplo, o Ensaio havia esboçado uma "teoria da música brasileira" e, devido à sua "originalidade", propunha, nos inícios dos anos 30 , a sua "tradução para todas as línguas" 36 .

No Ensaio, Mário defendeu a função social do artista (numa fase chamada de construção) - representada por um País atrasado - como o porta-voz do "povo" ou de uma "coletividade nacional". $\mathrm{E}$, assim, procurou negar o conceito de atraso outrora veiculado pelas elites republicanas da Belle Époque Tropical e intimamente associado à cultura popular.

Na Revista Brasil, em 1939, o autor de Macunaima reforçava essa temática: “... não nego, nem nunca neguei o direito de escrever música que se perdesse em liberdosas facilidades internacionais, e procurava lhes demonstrar que a mim me parecia errado..." 37 . Na verdade, Mário procurou redefinir o atraso das elites do país que desconheciam o "progresso" internalizado na 
música popular, ainda totalmente desconhecida pelos artistas e intelectuais.

Os chorões - excluídos sociais do Rio de Janeiro e São Paulo - foram marginalizados durante as reformas urbanísticas das duas primeiras décadas do século XX e isolados política e culturalmente pelas elites republicanas. Agora, esses excluídos sociais, nas "falas" de Mário de Andrade, metamorfosearam-se numa nova categoria social - o povo.

Para Mário, o "povo" transformou-se num agente, que disseminou nas mais diversas regiões do Brasil uma música "riquíssima" nas perspectivas rítmicas, timbrísticas, formais, tais como: o samba rural, o cateretê, o bumba-meu-boi, reisados, emboladas, moçambiques, coros. E competia ao compositor erudito inspirarse nessas fontes para criar uma Escola Nacionalista de Composição como o símbolo de uma coletividade e de uma Nação culturalmente independente...

Para exemplificar essa problemática altamente complexa no âmbito da escrita musical, em 1944, o Conselho de Orientação Artística de São Paulo patrocinou um concurso visando premiar a melhor sinfonia escrita por um autor brasileiro. Os organizadores desse concurso basearam-se nas "lamentações" de Mário de que, num período de vinte anos, somente haviam sido escritas no Brasil quatro ou cinco peças sinfônicas "esteticamente válidas". As normas desse concurso foram redigidas por Fúrio Franceschini, Caldeira Filho e Oneyda Alvarenga e "inspiradas" nos critérios de Mário sobre o "nacional "e o "popular" na música erudita brasileira: $1 .{ }^{a}$ ) as sinfonias apresentadas pelos concorrentes não deveriam limitarse a “... fazer citações folclóricas"; 2. a) o compositor deveria inventar “... intenção temática (...) sem a utilização de temas colhidos diretamente nas fontes do folclore musical brasileiro"; 3 . ") “... o compositor, aos termos das condições do concurso, teria realmente que se definir, como músico e como brasileiro" 38 .

Camargo Guarnieri - considerado por Mário como o seu principal discípulo - venceu esse concurso... Neste caso, historicamente, Camargo havia "internalizado", inconscientemente, "escutas" 
diversas do populário folclórico brasileiro, conseguindo, assim, escrever uma obra "esteticamente livre" e, paradoxalmente, aproximou-se das "teorias" verbalizadas pelo seu mestre - não-compositor - Mário de Andrade... E, paralelamente, as "escutas" de Mário em suas pesquisas folclóricas explicitaram-se nas suas concepções sobre o "som nacional", que foram "captadas" por Guarnieri em sua sinfonia premiada em 1944.

Mas essa "coincidência" histórica - Mário/Camargo - representou uma exceção e não uma regra na tradição do modernismo musical de 1928 a $1980 \ldots$

O Ensaio ou a Nova Carta do descobrimento do Brasil visou, em sua essência, envolver emotivamente o leitor-artista, almejando despertar-lhe o gosto pela pesquisa do folclore - música do povo - e induzi-lo, posteriormente, a escrever, interpretar e divulgar músicas modernistas, cumprindo, assim, a sua função social no momento da "construção" de um projeto em prol da criação de uma Escola Nacionalista de Composição capaz de consolidar um pólo cultural no Brasil, independentemente dos principais centros europeus...

\section{Entre Apolo e Dionísio: o Ensaio e a ideologização do vocabulário técnico-estético}

\section{1. "Atraso"?}

No Ensaio, Mário endossou, implicitamente, uma concepção teleológica da História da Música, presente nos trabalhos dos historiadores positivistas.

A História da Música no Brasil, conforme Mário, dividia-se em três períodos: $1 .^{\circ}$ ) de 1500 a $1822 ; 2 .^{\circ}$ ) de 1822 a $1914 ; 3 .^{\circ}$ ) pós-1914.

Para Mário, a música erudita no Brasil, durante o primeiro período, caracterizava-se pelo fenômeno de transplantação de obras de autores europeus, refletindo o "espírito subserviente da Colô- 
nia"39. De acordo com essa interpretação da História do Brasil Colonial, a música - predominantemente religiosa - prendia-se a manifestações artísticas "viciadas" ${ }^{40}$. Os cantos portugueses profanos eram divulgados através dos saraus promovidos pelas elites urbanas nos seus domicílios (sobrados) ou nas casas-grandes dos engenhos de açúcar, não denotando nenhuma "função histórica"41, e de óperas ou peças sinfônicas apresentadas nos teatros de Salvador, Rio de Janeiro, São Paulo: “... sem realidade nacional nenhuma"42. Para Mário, a música introduzida no Brasil pelos portugueses reproduzia, em sua essência, uma canção teatral “ ... melodista, bonitota, sem tradição" ${ }^{\prime 3}$.

De acordo com Mário, durante o primeiro período, somente com a vinda de $\mathrm{D}$. João tornou-se possível intensificar as atividades artísticas na cidade do Rio de Janeiro, apoiadas nos músicos oriundos da Fazenda de Santa Cruz e nas apresentações de obras escritas pelo padre José Maurício Nunes Garcia, Marcos Portugal, entre outros, inaugurando-se uma "fase de esplendor para a música" entre 1808 e $1822^{44}$.

O segundo período inciou-se com a independência política - 7 de setembro de 1822 - e foi caracterizado, em linhas gerais, por Mário de Andrade pelo "empobrecimento musical" em função dos "abalos" políticos ocorridos durante o Primeiro Reinado (18221831) e o Período Regencial (1831-40). Mário analisou a vida de artistas de um lado, a partir das obras sobre a História Oficial e Política do Brasil divulgada em sua época (Oliveira Vianna, Oliveira Lima); e, de outro, acusou a elite dominante pela introdução da “... detestável moda de tocar piano, que já em 1856 fazia a Manuel de Araújo Porto Alegre chamar o Rio de Janeiro de 'a cidade dos pianos" "45. O Segundo Reinado (1840-89) caracterizou-se, conforme Mário, "... talvez como o período de maior brilho exterior da vida musical brasileira", em função da vinda de companhias de óperas do Exterior ou de pianistas estrangeiros que haviam se radicalizado no Brasil, tais como Artur Napoleão e Luís Chiafarelli. Com o advento da República em 1889, o Brasil "mergulhou" numa nova fase de decadência musical: "... veio a República. O Brasil 
principiou pela terceira vez a vida. Mas, desta feita, a música não. Se acentuou gradativamente a decadência do brilho anterior (...) Cantores continuaram temporadas, mas o público se desinteressava deles cada vez mais" ${ }^{36}$.

Para Mário, o período de 1889 a 1914 (da proclamação da República aos inícios da Primeira Guerra Mundial), a "decadência musical" havia ocorrido no Brasil devido às seguintes causas: 1. a) a forte oposição entre a arte moderna e o gosto do "povo"; 2. a) Buenos Aires transformou-se no principal pólo cultural da América do Sul, atraindo, hegemonicamente, a vinda de artistas estrangeiros. Por esse motivo, São Paulo e Rio de Janeiro tornaram-se conhecidas pelos empresários como "terras de passagem"; 3. a) os repertórios operísticos e de músicas para concerto dessas Companhias que se exibiam em curtíssimas temporadas em São Paulo e Rio de Janeiro appresentavam "velharias já tradicionalizadas no gosto do público"47. Envolvido com o projeto modernista, Mário criticou ácida e virulentamente as elites paulistas da Belle Époque, que freqüentavam o Teatro Municipal por "modismo" e eram profundamente "incultas", "bocejando", freqüentemente, "... diante da arte"

O terceiro período da História da Música no Brasil iniciou-se no Pós-Guerra (1918). Esse "momento mágico" foi caracterizado por Mário pelo surgimento de um "tempo novo", capaz de despertar no homem sua consciência sobre o ideal de nacionalização de todas as artes.

A lenta e embrionária consolidação da música brasileira erudita, de acordo com Mário, ocorreu com a fundação da Sociedade de Concertos Sinfônicos em 1921 e com a criação do Departamento Municipal de Cultura em 1935. Essas instituições contribuíram para a divulgação de obras de compositores do período pós-1918, momento de eclosão de uma "verdadeira revolução" e "ruptura" da música no Brasil em face do seu "passado retrógrado". Neste período, alguns intérpretes ainda vacilaram no sentido de assumir ou não a chamada função social do artista. De acordo com Mário, a adesão dos intérpretes deu-se de “... uma maneira um pouco insatisfatória (...) a função nacional deles é bem pequena (...) e 
levados pelos interesses de camaradagem e outros interesses, botam nos programas peças de nomes estrangeiros (do país em que estão, pra agradar...), de valor mínimo, ao passo que não executam os compositores brasileiros muitas vezes superiores a esses estrangeiros" $"$.

A função social do artista, conforme Mário, prendia-se, fundamentalmente, na inclusão de obras de autores brasileiros modernistas nos programas de seus concertos a serem apresentados nos teatros das cidades brasileiras.

A arte praticada no Brasil até 1914, para ele, era essencialmente européia, mesmo entre os "nacionalistas" interessados na "representação musical da coisa brasileira" Gomes, Alexandre Levy, Alberto Nepomuceno, Francisco Manuel da Silva. $\mathrm{Ou}$, ainda, pelos compositores fortemente influenciados pelo "exotismo", como Leopoldo Miguez, Henrique Oswald, Francisco Braga, João Gomes de Araújo, Barroso Neto, Glauco Velasquez. Devido a essa fatalidade histórica, inexistiu no Brasil uma "música popular autêntica", capaz de servir de fonte de "inspiração" para os artistas eruditos, de 1500 a 1914-18. Os cantos populares - consoante essa "interpretação da História do Brasil"- eram de "raízes" predominantemente africanas ou portuguesas ou indígenas. Mário achava "ridículo" considerar esses cantos, ainda não-nacionalizados, como se fossem " brasileiros"

Apesar dessa visão "pessimista" do passado histórico, Mário procurou apontar algumas "originalidades" rítmicas ou melódicas em trechos de obras escritas por Carlos Gomes, tais como: $O$ Guarani e Lo Schiavo, que se "aproximavam" de alguns matizes já internalizados na melódica "popular brasileira". Entretanto, esse "ruim esquisito" presente nessas peças de Carlos Gomes, numa fase de construção - música de combate social - a ser aflorada pós1918 no Brasil - não poderia servir de exemplo para os jovens compositores da atualidade, somente "a vida e a intenção dele podem nos servir de exemplo"52.

E, a partir da construção do discurso modernista, Mário definiu os fatos históricos, selecionando datação presa à sua concep- 
ção de verdade histórica no campo da música: a) 1922; b) 1928. Essa cronologia prendeu-se a "momentos" considerados "decisivos" na descoberta das "falas populares" pelos artistas eruditos em algumas de suas obras, tais como: Heitor Villa-Lobos, Lorenzo Fernandez, Francisco Mignone, Camargo Guarnieri.

De acordo com Mário, a música popular aflorou, em toda a sua plenitude, nos anos 10 e 20 , através de uma complexa "deglutição" de elementos "estranhos" e "díspares", tais como : a) a influência ameríndia (formas: cateretê, cururu, modos "gregorianos", acalanto); b) influência portuguesa: fixação do tonalismo harmônico; formas - moda, fado; de instrumentos - violão, viola; c) influência africana (danças dramáticas; variedade rítmica; formas - como exemplo, lundu); d) influência espanhola (danças); e) influência das Américas (jazz, habanera, tango). E, assim, ientamente, o "povo brasileiro inculto" deglutiu, antropofagicamente, todas essas "influências", reiventando novas constâncias rítmicas, melódicas, morfológicas representativas da "musicalidade brasileira" 53 .

De acordo com essa "interpretação da história cultural do Brasil", o Ensaio escrito por Mário de Andrade em 1928 simbolizou um grito de alerta e uma exortação cívico-patriótica e doutrinária, almejando sensibilizar e convocar o artista para se engajar numa cruzada em prol do "descobrimento" da realidade, ainda desconhecida pela elite cultural.

Muitos críticos, artistas modernistas, intelectuais estrangeiros partidários dessa tendência estético-social escreveram artigos nos periódicos ou proferiram conferências sobre a "riqueza da musicalidade dos brasileiros". Mário de Andrade admitia chamar a atenção sobre: "essa musicalidade é real, porém, até agora deu melhores frutos no seio do povo inculto que na música. Muito mal está fazendo a falta de uma cultura tradicional, a preguiça em estudar, a petulância com os eruditos brasileiros, que filhos d'algo, filhos ou descendentes de senhores de engenho, de espanhóis, de alemães, de judeus russos se consideravam logo gênios insolúveis, por qualquer habilidade de canário que a terra do Brasil lhe deu. 
Nos consola é ver que o povo inculto criando aqui uma música nativa que está entre as mais belas e mais ricas" $54(.$.$) "os "sujeitos$ importantes' devem dar a importância deles pros homens populares, mais importantes que os tais. Se deve registrar tudo o que canta o povo, o bom e o ruim, mesmo porque desse ruim ninguém sabe tudo que pode tirar um bom. E finalmente se deve homenagear os Nazarés e os Tupinambás, os Eduardo Santos e as Francisca Gonzagas que criam pro povo e por ele" $" 55$. E, paralelamente, criticava a hostilidade dos imigrantes estrangeiros em face da música brasileira: "as próprias sociedades musicais do Rio e de São Paulo, tem como grosso dos seus sócios, estrangeiros, na sua maioria oriundos de países germânicos. E israelitas. É uma coisa deprimente 1939 - de se observar a pressão bastarda que sofrem essas sociedades para não executar música brasileira (...). Esses sócios estrangeiros, indiferentes ao país e dotados só de cultura tradicional, não compreendem, se irritam, não aplaudem as peças brasileiras do progresso. Então se o concerto é só de música brasileira, o teatro fica às moscas..."

Mário de Andrade almejava reinventar a História para denunciar, de um lado, o mimetismo dos artistas brasileiros em face das culturas "tradicionais" da Europa, e, de outro, chamar a atenção dos compositores eruditos sobre a riqueza e a exuberância da música popular criada pelo "povo inculto" e aculturada in totum durante a década de 1910.

Em 1928, Mário denunciou o atraso musical do Brasil, devido às seguintes "causas": 1. ${ }^{a}$ ) o melodismo de um Carlos Gomes; 2. a) o parnasianismo, que "veio perturbar violentamente a evolução da língua nacional e de nossa psicologia lírica, que os românticos estavam criando"s7. 3. a) o ensino tradicional (virtuosismo; peças românticas) do piano; $4 .^{\text {a }}$ ) apego dos intérpretes e empresários às obras de compositores europeus e consagradas pela crítica e pelo público; 5. a) o individualismo do artista não preocupado com a sua função social num País "atrasado" e totalmente "desinteressado pelas coisas brasileiras"; 6. ${ }^{a}$ ) a internalização consciente de traços exóticos das culturas populares nas obras de alguns compo- 
sitores brasileiros, que visavam "agradar" críticos e públicos estrangeiros (ritmos sincopados; "batuques bravos"); entre outras.

Implicitamente, 1928 simbolizou, para os "herdeiros" do projeto marioandradino, o marco zero de uma Nova História da Música Brasileira. O "progresso" atrelava-se a essa fase de construção marcada pela função social e não estética do artista: "uma arte nacional já está feita na inconsciência do povo. O artista tem só que dar pros elementos já existentes uma transposição erudita que faça da música popular, música artística, isto é: imediatamente desinteressada" 58. A noção de "progresso" ou de utopia, conforme Mário, concretizar-se-ia através de uma tomada de consciência do compositor erudito, dos intérpretes, dos empresários, dos críticos, dos professores, dos intelectuais, pela música popular e brasileira existente nas "falas" do "povo inculto".

A partir dessa dicotomia "atraso/progresso", implícita no Ensaio, Mário atacou, virulentamente, o primitivismo estético proposto por Oswald de Andrade no poema "Pau-Brasil": “... é um engano imaginar que o primitivismo brasileiro de hoje é estético. Ele é social (...) o lirismo de Osvald de Andrade é uma brincadeira desabusada. A deformação empregada pelo paulista não ritualiza nada, só destrói pelo ridículo. Nas idéias que expõe não tem idealismo nenhum. Não tem magia. Não se confunde com a prática. É arte desinteressada. Pois toda arte socialmente primitiva que nem a nossa, é a arte social, tribal, religiosa, comemorativa. É arte de circunstância. É interessada. Toda arte exclusivamente artística e desinteressada não tem cabimento numa fase primitiva, fase de construção. É intrinsecamente individualista. E os efeitos do individualismo artístico no geral são destrutivos (...) O critério atual da Música Brasileira deve ser não filosófico mas social. Deve ser um critério de combate. A força nova que voluntariamente se desperdiça por um motivo que só pode ser indecoroso (comodidade própria, covardia ou pretensão) é uma força antinacional e falsificadora" 59 .

Para Mário, essa fase de construção, somente iria ocorrer futuramente, com os "jovens artistas" envolvidos pelo "clima" dos 
"novos tempos". Nos anos 20 surgiram as primeiras tentativas dessa "aliança" caracterizada pela "aproximação" dos artistas eruditos em face da música criada pelo "povo". Entretanto, essas obras, "inspiradas" no imaginário popular, foram escritas mediante a utilização de "técnicas" muito "diferentes". Essas músicas eram, em geral, elogiadas por Mário, pois simbolizavam uma possível aproximação "interessada" entre o artista culto e as "coisas brasileiras": "... Tupinambá, se não expressa a civilização um pouco exterior das cidades modernas do Brasil, Rio de Janeiro, São Paulo, congraça nas suas músicas a indecisa alma nacional, a que domina profunda melancolia. Nessa página chamada Minha Terra, ele disse admiravelmente na primeira parte o que vai de preguiça, de cansaço e de tristeza nostálgica pelo nosso vasto interior, onde ainda a pobreza reina, a incultura e o deserto (...) Não se ouve mais o Matuto. Ninguém mais se lembra de Ao som da viola. Mas é possível que um dia os compositores maiorais, conscientes da sua nacionalidade e destino, queiram surpreender a melodia mais bela e original do seu povo. As músicas de Marcelo Tupinambá serão nesse dia observadas com admiração e mais constância"

E, paralelamente, denunciava o artista "comprometido" com as raízes nacionalistas não-brasileiras": "... mas tenho que reconhecer que a situação atual de Francisco Mignone - 1928 - é bem dolorosa e que estamos em risco de perder, perdendo-o, um valor brasileiro útil. (...) Mas que valor nacional tem o Inocente? Absolutamente nenhum. E é muito doloroso no momento decisivo de normalização étnica em que estamos, ver um artista nacional se perder em tentativas inúteis..."61.

A fase de construção de um projeto em prol da nacionalização da música erudita brasileira fundamentava-se, em síntese, no compromisso social do compositor em face do "resgate" dos valores culturais de um País agrário e rural: "a atualidade brasileira se aplica aferradamente a nacionalizar a nossa manifestação. Coisa que pode ser feita e está sendo sem nenhuma xenofobia nem imperialismo. $\mathrm{O}$ critério histórico ${ }^{62}$ atual da Música Brasileira é o da manifestação musical que sendo feita por brasileiro ou indivíduo 
nacionalizado, reflete as características musicais da raça. Onde que estas estão? Na música popular"63.

Nesta fase de construção, ao se referir ao artista brasileiro envolvido com a música estrangeira ou internacional como "um inútil, um nulo. Uma reverendíssima besta", se não for um "gênio"64, Mário não estava preocupado com o surgimento de possíveis "gênios", mas com autores capazes de internalizar a problemática modernista: "em primeira audição, os Cantos Populares 1931 - Brasileiros, do compositor paulista Artur Pereira. São onze pecinhas pra côro e orquestra, sobre temas populares. $\mathrm{O}$ trabalho de Artur Pereira é inteligentíssimo"65.

\section{2. "Exotismo, individualismo, exclusivismo"/6" nacionalismo inconsciente, coletivismo"}

No Ensaio, e nos seus inúmeros artigos, Mário atacou, agressiva e ironicamente, o exotismo apropriado consciente e propositalmente pelo compositor em face de alguns recursos sonoros "fáceis", oriundos da música popular, visando somente "agradar" e "envolver" críticos e públicos estrangeiros interessados nos aspectos "superficiais" e "programáticos" do discurso sonoro: "um dos conselhos europeus que tenho escutado bem é que a gente si quiser fazer música nacional tem que campear elementos entre os aborígenes pois só mesmo estes que são legitimamente brasileiros. Isso é uma puerilidade que inclui ignorância dos problemas sociológicos, étnicos, psicológicos e estéticos. Uma arte nacional não se faz com a escolha discricionária e diletante de elementos: uma arte nacional já está feita na inconsciência do povo. $\mathrm{O}$ artista tem só que dar pros elementos já existentes uma transposição erudita que faça da música popular, música artística, isto é: imediatamente desinteressada" $"$.

Mário defendia a "música popular" como "matéria-prima" ou "fonte" de inspiração a ser antropofagicamente deglutida pelo compositor erudito. Nas suas obras, a utilização de fragmentos rítmi- 
cos ou melódicos de músicas africanas ou indígenas pelo compositor colocavam em xeque o projeto modernista calcado no inconsciente coletivo de uma Nação. O emprego exclusivista de alguns signos da música negra, como por exemplo o ritmo sincopado, poderia induzir o compositor a escrever uma obra "agradável" e sintonizada com os emblemas de uma Nação africana não-brasileira... E, assim, o compositor estaria negando, através do exotismo, a criação de um "rosto musical" sui generis de uma Nação chamada Brasil...

No período de 1922 a 1945, Mário criticou, com virulência, a internalização de traços considerados exóticos e individualistas nas obras dos compositores eruditos, incluindo os seus autores prediletos, tais como: Heitor Villa-Lobos, Camargo Guarnieri, Lorenzo Fernandez, Francisco Mignone. No Ensaio, criticou a utilização excessiva de temas indígenas em algumas obras de VillaLobos, que concorreram "pro sucesso atual do artista" ${ }^{27}$. Para não magoar ou criar "inimigos" entre os artistas capazes de concretizar o "programa modernista", Mário sempre procurava atenuar suas críticas mais "ácidas" através da inclusão, nos seus artigos, de frases onde procurava enfatizar a "genialidade" do compositor: "ninguém não imagine que estou diminuindo o valor de Villa-Lobos, não. Pelo contrário: quero aumentá-lo. Mesmo antes da pseudo-música indigena de agora ${ }^{68}$ Villa-Lobos era um grande compositor. A grandeza dele, a não ser pra uns poucos sobretudo Artur Rubinstein e Vera Janacopulos, passava despercebida. mas bastou que fizesse uma obra extravagante bem do continuado, pra conseguir o aplauso"69.

Para Mário de Andrade, os "sucessos" alcançados pelos Oito Batutas e Villa-Lobos em Paris, em 1922 e 1923, respectivamente, prenderam-se a uma prática artística "mais individual que nacional" 70 . Em algumas de suas críticas, Mário elogiava os oito artistas que haviam conseguido afastar-se dos "fantasmas" do exotismo e do individualismo: "felizmente que já passou aquele tempo amaldiçoado em que os nossos compositores quando faziam música brasileira, faziam isso como se fosse mera concessão pro exótico. 
Nestes novos - Lorenzo Fernandez, por exemplo, de agora, que aliás não poderiam ser o que são si não fosse o trabalho dos antecessores, a gente já nota uma naturalidade e fatalidade nacionais do melhor calibre..."

Irônica ou tragicamente, esses "fantasmas do passado" continuaram "atormentando" Mário de Andrade até o seu falecimento, ocorrido em 1945: "não pude concordar com Francisco Mignone em ter preferido as danças à abertura do Guarani. As danças, ouvidas assim, sem o disfarce do bailado e o divertido de muitos penachos saltitando em busca de coreografias, provaram bastante a sua facilidade musical (...) O Imbapara de Lorenzo Fernandez nos transporta da música de influência negra para a música baseada em possíveis temas ameríndios. Confesso que duvido muito desses temas, sob o ponto de vista étnico, mas o importante é que são bons temas musicais (...) por mais bem feitos que sejam poemas como o Imbapara, sempre é certo que pouco ou nada nos falam à alma nacional"72. E sobre a melodia de Heitor Villa-Lobos: "trata-se de uma peça de escasso valor, espécie de rapsódia de todos os lugares comuns do arabismo do século passado"73.

De acordo com essa concepção de história, somente Johann Sebastian Bach; Wolfgang Amadeus Mozart; Ludwig van Beethoven, por exemplo, poderiam ser chamados de "gênios". Por que? Devido a uma fatalidade histórica, esses compositores escreveram obras "nacionais" que se transformaram em "universais", devido a um feliz "encontro": função social do artista + "elevadíssimo teor estético" de suas obras. No Brasil dos anos 20 e 30, em função do atraso do País - de acordo com Mário - seria preferível que o jovem compositor, no início de sua carreira, abraçasse o imaginário nacionalista, e assim, opondo-se ao exotismo e ao individualismo, paulatinamente, poderia caminhar em direção à "universalização" de sua obra num futuro próximo...

Nesta fase de construção, seria preferível que o compositor se voltasse para a pesquisa da música popular: "Cesar Cui seria ignorado si não fosse o papel dele na formação da escola russa. Turuna é de importância universal mirim"74. Por essa razão, Mário 
procurou enfatizar obras de compositores brasileiros - Heitor VillaLobos, Camargo Guarnieri, Lorenzo Fernandez, Clorinda Rosato, Elza Cameu - de matizes socializantes, aproximando-os de Cesar Cui e afastando-os de um Turuna...

Entretanto, Mário sempre procurou criticar, com veemência, o ufanismo e a xenofobia, opondo-se, assim, às propostas políticoculturais do Grupo "Verde-Amarelo": "a marchinha central dos admiráveis Choros n. 5 de Villa-Lobos (Alma Brasileira) foi criticada por não ser brasileira. Quero só saber porquê. $\mathrm{O}$ artista se utilizou de um ritmo e dum tema comuns, desenvolvidos dum elemento anterior da peça, tema de caráter imediatamente étnico nenhum (...) tanto podendo ser brasileiro (...) não só porque sendo inventado por brasileiro dentro de peça de caráter nacional e não levando a música pra nenhuma outra raça, é necessariamente brasileiro"75/76.

\section{3. "Nacional" / "universal"?}

Para Mário de Andrade, a música "universal" representava "um esperanto hipotético, que não existe (...). Não há música internacional e muito menos música universal: o que existe são gênios que se universalizam por demasiado fundamentais, Palestrina, Bach, Beethoven..."

Utopicamente, a "universalização" da música brasileira erudita somente poderia ocorrer num futuro longínquo, através do surgimento de obras "esteticamente livres"... Trágica ou ironicamente, esse critério em prol da nacionalização da música bràsileira harmonizou-se nos anos 40 e 50, com alguns traços do jdanovismo ou do realismo socialista ${ }^{78}$. Alguns dos matizes do jdanovismo já haviam-se esboçado no Ensaio em 1928: "mas (...) um artista brasileiro escrevendo agora ${ }^{79}$ em texto alemão sobre assunto chinês, música da tal chamada de universal faz música brasileira e é músico brasileiro. Não é não. Por mais sublime que seja, não só a obra não é brasileira como é antinacional. E socialmente o autor dela 
deixa de nos interessar. Digo mais: por valiosa que a obra seja, devemos repudić-la ${ }^{80}$, que nem faz a Rússia com Strawinsky e Kandinsky" ${ }^{1 / 82}$. Neste trecho, Mário revelou um matiz apolíneoautoritário do seu pensamento, aproximando-se dos ensaios escritos por Cassiano Ricardo e Plínio Salgado durante os anos 30: "estamos procurando conformar a produção humana do país com a realidade nacional" 83 .

Somente através de um projeto de modernização do País, poder-se-ia, de acordo com Mário, criar o ideal de "coletividade" ou de "comunidade" (Nação + povo versus antagonismos ou conflitos sociais), privilegiando o "povo" como o "motor" da História do Brasil. E, a partir dessa conjuntura, seria possível criar uma Escola Nacionalista de Composição, sintonizada com a "alma do povo": "dia em que nós formos inteiramente brasileiros e só brasileiros a humanidade estará rica de mais uma raça, rica de uma nova combinação de qualidades humanas (...) Nossos ideais não podem ser os da França por que as nossas necessidades são inteiramente outras, nosso povo é outro, nossa terra é outra etc. Nós só seremos civilizados com relação às civilizações o dia em que criarmos - o ideal de orientação basileira. Então passaremos da fase do mimetismo, pra fase de criação. E então seremos universais, por que nacionais (...) como os norte-americanos do século $20 " 84$.

Com a expansão da indústria do entretenimento nas cidades do Rio de Janeiro e São Paulo nos anos 30 - teatros de revista, emissoras de rádio, indústria do disco, cinema sonoro, dancings, cassinos -, muitos compositores e intérpretes divulgaram centenas e centenas de músicas inspiradas no imaginário folclórico, que se tornaram modismo. Essas músicas, de fortes colorações "regionalistas", aproximaram-se indireta e inconscientemente de questões ideológicas levantadas por Mário no Ensaio.

Nos anos 20, em São Paulo, por exemplo: "Cornélio Pires instaura uma prática que lhe traria enorme popularidade, partindo para viagens a rincões remotos do sertão, que eram em seguida relatadas em bem-humoradas conferências e saraus regionalistas, sempre com os teatros lotados e lutas pelos bilhetes. Artistas e 
arquitetos paulistas partem para viagens de 'estudos' pelos interiores, com visitas obrigatórias às cidades históricas de Minas e capitais do Nordeste..."85, " ... o entretenimento se assinalava justamente por sua integração com o processo capitalista, pois visava conquistar um mercado que não se limitava apenas ao Distrito Federal. O rádio e o cinema acenavam com a possibilidade de participação de boa parte da nação e se constituíam em uma indústria de massa, brasileira ou importada, vendendo em seu mercado os bens a consumir, os filmes e as canções, ou às vezes, os dois simultaneamente" 86 .

Em geral, Mário de Andrade criticou, com veemência, de um lado, os maxixes, sambas, tangos, ragtimes divulgados pelos artistas populares através do rádio ou do teatro de revista; e, de outro, os compositores eruditos sem conhecimentos técnicos e estéticos mais rigorosos, que parafrasearam temas das canções folclóricas.

Para combater esse modismo inspirado diretamente na canção folclórica durante os anos 30, Mário, em 1933, defendeu uma quarta fase ou etapa a ser percorrida pelo artista erudito na sua busca utópica do "som nacional". Essa fase, chamada de cultural, caracterizava-se pela "independência total" do artista em face aos "fatos folclóricos". A obra do artista deveria ser "esteticamente livre..."

Nos anos 30, Mário percebeu que muitos compositores modernistas, incluindo alguns dos seus alunos do Conservatório Dramático e Musical de São Paulo, escreveram músicas baseadas diretamente nas temáticas folclóricas, consideradas como as fontes da brasilidade pelas mais diversas tendências político-partidárias desse momento histórico. Esses compositores escreveram centenas de peças que se transformaram em verdadeiros pastichos das canções folclóricas. E, de repente, Mário de Andrade tornou-se "prisioneiro" de sua utopia neste momento de construção do imaginário modernista. De um lado, surgiram compositores "menores" e, de outro, compositores consagrados - Heitor Villa-Lobos, Camargo Guarnieri, Francisco Mignone, Lorenzo Fernandez - que conseguiram internalizar, em algumas de suas obras, traços "coletivistas" 
e esteticamente livres. Entretanto, Mário transformou-se num refém do seu projeto: os compositores modernistas decodificaram as suas "escutas" do folclore anônimo em prol de uma busca de obras de matizes "coletivistas" e acabaram produzindo sonoridades muito semelhantes...

A partir das "escutas" dessas músicas eruditas, Mário constatatou uma ausência de estilo nesses artistas que, paradoxalmente, passaram a representar as falas de um "povo culto"... Por esse motivo, influenciado pela estética formalista, exigiu desses compositores uma preocupação mais rigorosa com a escrita musical, aconselhando-os no sentido de libertá-los das influências diretas do folclore. Entretanto, essas exigências de Mário esbarraram na inexistência de tratados teóricos no campo do modernismo cultural. Cada compositor procurou conciliar seus estudos técnicos com as especificidades rítmicas, timbrísticas das canções folclóricas de acordo com uma visão de mundo considerada muito "individualista" dessa problemática.

Mário de Andrade - nos fins dos anos 30 e inícios da década de 1940 - valorizou os compositores capazes de criar músicas "originais", "inconfundiveis", opondo-se às disparidades regionais e ao pluralismo das escolas nacionalistas devido à expansão de projetos culturais implementados pelos Estados Totalitários e Autoritários, tais como: Alemanha (nazismo e a valorização do folclore ariano); Itália (apologia e divulgação das obras dos mitos românticos da ópera do século XIX, em especial); Rússia (stalinismo e a concretização do realismo socialista, sistematizado por Jdanov a partir de 1932); Brasil (valorização do ensino do canto orfeônico como um dos pilares da formação cívica do cidadão, sob o getulismo: 1930-45); entre outros.

Com a eclosão da Segunda Guerra Mundial em 1939, Mário conscientizou-se sobre os "perigos" da utilização da palavra "nacionalismo", amplamente internalizada, sob matizes diversos, nos discursos integralistas; liberais conservadores; socialistas; nazistas; fascistas; modernistas. Por esta razão, preferiu utilizar o adjetivo nacional - para continuar explicando e fundamentando a sua con- 
cepção sobre a música brasileira erudita. Com o acirramento aflorado entre os nacionalismos políticos pós-1939, Mário temeu um possível desencadeamento de uma guerra "cultural" entre as Nações envolvidas no conflito. Os Estados vencedores poderiam impor o seu modelo nacionalista na música, dominando culturalmente as Nações perdedoras.

Nessa conjuntura histórica - 1939-45 -, Mário percebeu as possíveis "ameaças" de uma invasão wagneriana no Brasil, caso a Alemanha vencesse a guerra, "implodindo" a sua utopia sobre o modernismo musical... E, sentindo-se "prisioneiro " de uma ditadura - Estado Novo (1937-45) -, escreveu o Banquete (1944-5), onde apontou metaforicamente todas as angústias e dilemas de Janjão - compositor nacionalista - em face das contradições sóciopolítico-culturais de um País chamado Mentira - que, através de umá instituição ou órgão de censura - GELO -, controlava todas as atividades artístico-culturais nos campos da música, cinema, teatro, imprensa, rádio, disco. O conteúdo doutrinário-programático do Ensaio, escrito em 1928, foi retomado por Mário no Banquete, sob ângulos estético-ideológicos redefinidos em função do surgimento de uma nova conjuntura histórica - a ditadura Vargas nunca prevista ou imaginada por um artista que sempre havia abominado a política partidária.

Em 1930, Mário, às vésperas do Golpe, afirmou: “... a decadência moral dos paulistas, já estigmatizados com tanta lealdade por Paulo Prado numa das páginas mais incisivas da 'Paulística', tinha chegado nestes últimos tempos a um estado de tamanho desleixo que atingira as raias do semvergonhismo. Foi por tudo isso que ainda mais me espantou a formidável recepção estritamente popular que os paulistas fizeram aos candidatos do Partido Liberal (...) um povo de certamente mais de cem mil pessoas, vibrando num cortejo gritador, todo ele tomado duma raiva dionisíaca, religiosa pela precisão de ver em alguém (...) Não houve tempo para inventar hinos. Mas tinha um que é nossa propriedade, o Nacional, e esse foi cantado, gritado, desafinado, imposto, estragado, dignificado pela multidão, com esse direito que ela tem de ser maravi- 
lhosamente feia (...) Pois na falta de hinos de circunstância e de cantigas apropriadas, o povo paulista se agarrou às dinamogenias rítmicas, que são mais fáceis de lembrar e mais incisivas psicologicamente. Foram numerosas as que surgiram na noite de sábado passado. Consegui colher as seis que vão aqui. São todas interessantíssimas pelas palavras e principalmente pelos ritmos criados (...) Não estou no momento fazendo considerações partidárias. Não tem dúvida que odeio esta República e especialmente o caudilhismo governamental que nos anda envilecendo, porém fóra dos partidos e dos ódios, o que me interessa mesmo filialmente, é a perfeição e integridade do povo"s7.

No Banquete (1944-45), Sarah Light - milionária, "plutocrata", israelita, nascida em Nova Iorque, "sem raízes" - defendia a arte como privilégio da classe social dominante, demonstrando uma "pseudo oposição" em face da ditadura getulista; Félix de Lima de origem italiana, "naturalmente fascista" "88 "burro e ignorante", defensor das instituições vigentes; Siomara Ponga - cantora virtuose de renome, de origem espanhola, "acadêmica", opunha-se a Janjão, "o sincero criador" 89 .

No Banquete, Mário continuou não resolvendo os impasses técnico-estéticos entre o artista erudito e a pesquisa da música popular. Implicitamente, conscientizou-se sobre o "desaparecimento" do folclore devido à crescente modernização da sociedade capitalista, mas continuou defendendo a função social do artista, agora inspirando-se no marxismo através da busca de uma vida melhor e da felicidade, sem contudo abraçar o ideal da "arte proletária" ou "arte engajada", consoante critérios conteudísticos e pouco formais impostos pelo realismo socialista...

\section{4. "Música popular (folclórica)"; "Arte Culta" / "Música popularesca"}

A pesquisa do folclore tornou-se, durante os anos 30,40 e 50 , o ponto nodal dos ensaios escritos sobre a "identidade nacio- 
nal" pelos integralistas, liberais conservadores e autoritários, socialistas, estadonovistas, modernistas. Essa busca da identidade e unidade culturais inspiradas no folclore, pode ser resumida nesta afirmação de Napoleão Albuquerque: “ ... as investigações perseverantes, capazes de estabelecer com segurança, os fundamentos em que se deverá erigir a verdadeira expressão musical da nossa raça..."

Muitos intelectuais enalteceram a música popular ou folclórica como a principal fonte de inspiração do compositor erudito, numa etapa capaz de identificar a música como símbolo da "alma de uma Nação". De acordo com esse ideal, a "arte universal" passou a simbolizar uma "arte nacional em seu mais alto clímax".91.

Os critérios estabelecidos pelos críticos, historiadores da música ou pelos ideólogos do Estado Novo (1937-45) apresentaram, em linhas gerais, algumas concordâncias sobre os conceitos de "música nacional"/ "música universal". Para Andrade Muricy, em 1931, a internalização do "nacional" na música ocorreu somente nas obras escritas por Heitor Villa-Lobos, Lorenzo Fernandez e Luciano Gallet, secundados pelo “... grande crítico e folclorista Mário de Andrade, autor do magistral Ensaio sobre a música brasileira..."

Historicamente, o forte impacto do nacional-popular nas obras ensaísticas (verbalizadas) e musicais (não-verbalizadas) dos intelectuais dos anos 30 e 40 favoreceu "explicações" altamente matizadas sobre as "escutas" das chamadas músicas folclóricas, populares, popularescas e eruditas ${ }^{93}$, contribuindo, de um lado, para o enaltecimento, e, de outro, para o "silenciamento" ou "extermínio" dos compositores verdadeiramente brasileiros ou meros imitadores das músicas produzidas nos pólos culturais alienígenas... $\mathrm{Na}$ citada fala de Andrade Muricy, por exemplo, somente os compositores eruditos cariocas foram "elogiados"- Villa-Lobos, Lorenzo Fernandez, Luciano Gallet - deixando-se de lado os chamados "popularescos" - Ernesto Nazareth, Sinhô, Noel Rosa ou os eruditos "paulistas", tais como Camargo Guarnieri e Francisco Mignone, entre outros. 
Os trechos de colorações cívico-patrióticas do Ensaio sobre o Canto Coral tornaram-se unanimemente aceitos por todas as tendências político-culturais. A temática sobre o civismo vinha sendo colocada por alguns intelectuais a partir dos inícios dos anos 20: "uma agitação nova e jovial faz fremir o país por todos os lados. A pátria canta e todos os seus progressos se simbolizam nesse trabalho musical glorioso que exprime as nossas forças vivas (...) E o Brasil prova com a sua musicalidade atual, imperiosa e rica, como o seu corpo anseia por ocupar a parte que lhe está destinada no convívio amoroso da terra civilizada" ${ }^{44}$.

Esse clima "otimista", de matizes cívico-patrióticos, aflorou na música durante os anos 20, como uma espécie de contradiscurso em face da política cultural liberal implementada pelo Partido Republicano. E o folclore transformou-se na principal fonte temática dessas canções da brasilidade. No Ensaio, Mário procurou indicar, em linhas muito gerais, os traços originais e singulares do cancioneiro folclórico brasileiro, almejando "distanciá-los" da sintaxe tradicional da música européia. Por exemplo, Mário apontava a passagem do Modo Maior para o Modo menor como uma característica sui generis e fundamental da modinha, chamando a atenção para a importância desse problema a ser estudado com rigor pelos compositores modernistas. Ou seja, esse artificio, internalizado anônima e coletivamente pelo "povo" na modinha, representava "o jeito característico ou a maneira modulatória racial"95.

Mário de Andrade, nos seus artigos, não desprezou in totum a música popular urbana, que havia se expandido vertiginosamente nos anos 30 e 40 . Em suas críticas, ora elogiava algumas músicas escritas por Marcelo Tupinambá, Francisca Gonzaga ou Noel Rosa, ora criticava, com virulência, músicas escritas pelos compositores sob encomenda dos empresários das emissoras de rádios, do disco ou dos teatros, em especial, as obras "contaminadas" pelo "vírus" do tango ou dos filmes musicais norte-americanos (fox-trot) durante os anos 30. O tango (Argentina); a chanson (França); o foxtrot (Estados Unidos), por exemplo, colocavam em xeque as "falas" verdadeiras do "homem rural" ou dos subúrbios das grandes 
cidades: “... a forma musical da Suite é positivamente uma das preferidas pela nossa gente. Está nos fandangos de Cananéia, se manifesta no Congado, no Maracatu, no Boi-Bumbá, no Pastoril (...) Nas emboladas, nos coros, nos desafios, nos pregões, nos aboios, nos lundus e até nos fandangos, a gente colhe formas do metro musical livre e processos silábicos e fantasistas de recitativo, que são normais por aí tudo no país. Isso os artistas carecem observar mais"96.

Para Mário, o "fato folclórico", num primeiro momento histórico, teria sido inventado por um artista culto, letrado, e, num segundo, "reinventado" pelo "povo inculto". Por essa razão, muitos compositores, imbuídos desses ideais de brasilidade, temeram a "cidade" ou o "mundo urbano" como o local da "degradação" da música, devido às fortes influências de sons estrangeiros divulgados através das emissoras de rádio ou pelas indústrias do disco ou pelos filmes sonoros ou pela forte presença de imigrantes vindos da Itália, da Espanha, do Japão, da Turquia, da Alemanha, em especial, na cidade de São Paulo. Essas canções estrangeiras, conforme esse pensamento, poderiam "contaminar", a partir de 1928, a música brasileira "autêntica", levando-a a um total "desaparecimento"...

Lúcio Rangel, um dos principais historiadores da música popular brasileira, não conseguiu captar, com rigor, essa ambigüidade dos ensaístas, que ora valorizavam, ora desprezavam a música popular urbana. Na sua obra Sambistas \& Chorões, elogiou o interesse de Mário de Andrade pela pesquisa do samba rural paulista, mas não chegou a compreender o desinteresse do autor de Macunaíma pelo estudo sistemático do samba carnavalesco do Rio de Janeiro: "como nossos folcloristas, não sei porque, Mário também preferiu o estudo de certas manifestações musicais observadas em pequenos núcleos da população, do grande samba, cantado e dançado por milhões de brasileiros, embora influenciado pelas modas internacionais, como tinha que ser. Preferiu os caboclinhos, de João Pessoa ou do Rio Grande do Norte, o boi bumbá do Amazonas e as congadas da Vila de Lindóia"97. Na realidade, Mário 
interessou-se pelos temas do carnaval urbano como fontes de inspiração para o artista erudito: "o carnaval freqüenta raríssimamente a nossa arte erudita. Um quadro de Parreiras, um grupo de peças pianísticas de Villa-Lobos e mais nada importante que eu me lembre"98.

No Ensaio, Mário elogiou, com reservas, a gravação da embolada pernambucana - Pinião - pelos Turunas da Mauricéia, divulgada em $1927^{99}$, que se tornou grande sucesso do Carnaval do Rio de Janeiro de 1928. De acordo com os seus princípios, entre as três versões de Pinião, incluindo a peça gravada pelo grupo pernambucano, Mário apontou a versão anônima dessa embolada como a mais representativa e mais próxima da verdade histórica, por ter sido cantada, com maior rigor rítmico, "por pessoas do povo"100.

A música popular vista como a fonte histórica mais confiável pelo pesquisador, tornou-se o ponto nodal de inúmeros exemplos indicados por Mário no Ensaio e nos seus artigos, como por exemplo, os maxixes dançados pelo "povo do Rio de Janeiro", considerados como "... peças soberbas, onde a melodia ia se transfigurando num ritmo novo"; e, num segundo momento, criticou duramente "... os maxixes impressos de Sinhô", considerados como um conjunto de "... banalidades melódicas"101.

Nestes exemplos, Mário selecionou canções ou danças do "povo", sempre desconfiando ou criticando, com ironia, as suas versões popularescas e urbanas.

No caso do intenso diálogo entre o maxixe e o jazz, Mário interpretou essa aproximação polifônica em função de uma "fatalidade histórica" oriunda de um povo que migrou da África, ora para os Estados Unidos, ora para o Brasil, durante o século XIX. $\mathrm{O}$ tango argentino, muito divulgado no Brasil, foi acidamente criticado por Mário: "tem uma influência evidente do tango em certos compositores que pretendem estar criando a Canção Brasileira! Estão nada. Se aproveitam da facilidade melódica pra andarem por aí tangaicamente gemendo sexualidades panemas"102.

A antinomia mundo rural (jazz + maxixe) e mundo urbano (tango) denota, implicitamente, a concepção de Mário sobre uma 
verdade histórica criada pelo "povo inculto" e uma mentira histórica, implícita nas obras dos compositores populares urbanos, em geral.

\subsection{Polifonia + coletividade? / Harmonia + individualismo burguês?}

Na fase de construção de uma Escola baseada no ideal de nacionalização da música erudita brasileira, Mário de Andrade indicou, em linhas gerais, alguns critérios técnicos inspirados nas constâncias rítmicas, timbrísticas, melódicas das músicas populares folclóricas, tais como: $\left.1 .^{\circ}\right)$ nas pesquisas sobre o ritmo sincopado, procurou desmistificar uma noção generalizada entre os artistas sobre esse ritmo, visto como símbolo das "verdadeiras raízes da música brasileira". Para Mário, nos inúmeros documentos pesquisados, algumas melodias de origem africana baseavam-se na escala hexacordal (sem a nota sensível), como, por exemplo, a versão paraibana da canção Mulher Rendeira, na qual a sétima nota da escala diatônica é sistematicamente evitada, caracterizando-se pelos saltos melódicos considerados "audaciosos" (de 7. a ou de $\left.8 .^{a}\right) ; 2 .^{\circ}$ ) as melodias folclóricas eram entoadas, em sua maioria, através de frases descendentes, opondo-se à sintaxe tradicional do sistema tonal europeu; $3 .^{\circ}$ ) a escritura da maioria das canções folclóricas apoiava-se na linguagem polifônica: “... o problema da Harmonia não existe propriamente na música nacional. Simplesmente porque os processos de harmonização sempre ultrapassam as nacionalidades (...) porém esse caráter é muito nacionalizador aos processos harmônicos populares, pobres por demais. Tem que ser um desenvolvimento erudito deles (...) A não ser que a gente crie um sistema novo de harmonizar, abandonando por completo os processos já existentes na Europa (...) a harmonização européia é vaga e desraçada. Muito menos que raciais, certos processos de harmonização são individuais..."103.

No âmbito da linguagem musical, Mário de Andrade não podia refutar a harmonia "européia" como algo "nocivo" para a mú- 
sica modernista, devido à impossibilidade técnica e histórica de se elaborar uma nova linguagem compatível com o seu projeto, ou negar as fortes influências do tonalismo e do modalismo no folclore brasileiro. Em função dessa "nova fatalidade histórica", Mário procurou levantar algumas hipóteses genéricas e superficiais sobre essa problemática metodológico-teórica altamente complexa: "o problema é bem sutil e merece muito pensamento, muito raciocínio dos nossos artistas" ${ }^{104}$. Neste caso, os compositores eruditos deveriam observar, sutil e rigorosamente, os processos melódicos, rítmicos, timbrísticos internalizados nas canções folclóricas e, paralelamente, criar novos critérios harmônicos ou polifônicos, almejando nacionalizar, com eficiência, a música modernista brasileira. Para exemplificar a possibilidade de concretizar esses novos critérios, Mário citou peças escritas por Luciano Gallet e Camargo Guarnieri (Andante da Sonatina).

Essa ambigüidade metodológica foi indicada por Mário na parte sobre uma possível nacionalização das formas européias, como a sonata, sinfonia, fuga, suíte, pelos compositores modernistas. Para solucionar esse "novo impasse", propôs a invenção de formas inspiradas nos coros, desafios, emboladas, lundus, sambas, maxixes, chimarritas, catiros, cururus, mazurcas, valsas, polcas, "além das dinamogenias militares, dobrados, marchas (...) tudo isso está aí pra ser estudado e pra inspirar novas formas musicais na-cionais"105.

Mário de Andrade privilegiou o canto coral e a ópera como formas capazes de internalizar, com "eficiência", o projeto nacionalista: poética + sons.

$\mathrm{O}$ coral foi considerado por ele e pela maioria dos intelectuais nacionalistas dos anos 30 como a única forma capaz de representar o "retrato" ou o "perfil do rosto musical do Brasil Novo": "também quanto a formas corais possuímos nos reisados e demais danças dramáticas, e nos coros muita base de inspiração formal. Nos coros as formas corais variam esplendidamente. Ora eu insisto no valor que o coral pode ter entre nós. Musicalmente isso é óbvio. Sobretudo com a riqueza moderna em que a voz pode ser concebi- 
da instrumentalmente, como puro valor sonoro (...) Ainda aqui o exemplo de Villa-Lobos é primordial. Se aproveitando do cacofonismo aparente das falas ameríndias e africanas e se inspirando nas emboladas ele trata instrumentalmente a voz com uma originalidade e eficiência que não encontra exemplo na música universal (Sertaneja, Rasga Coração). Mas os nossos compositores deviam de insistir no coral por causa do valor social que ele pode ter. País de povo desleixado ${ }^{106}$ onde o conceito de Pátria é quase uma quimera a não ser pros que se aproveitam dela, país onde um movimento mais franco de progresso já desumaniza os seus homens na vaidade dos separatismos, país de que a nacionalidade, a unanimidade psicológica, uniformes e comoventes fazem pra desvirtuá-las e entregá-las, o compositor que saiba ver um bocado além dos desejos de celebridade, tem uma função social neste país. $\mathrm{O}$ coro humaniza os indivíduos. Não acredito que a música adoce os caracteres não (...) Carece que a espanholada do baiano se confraternize com a mesma baianada do governo (...) é possível a gente sonhar que o canto em comum pelo menos conforte uma verdade que nós estamos não enxergando pelo prazer amargoso de nos estragarmos pro mundo..."

Nesse debate sobre a função social do canto coral, Mário ora criticava o "povo desleixado", apático civicamente, ora convocava os compositores para escreverem peças corais, inspirando-se nos temas do "povo inculto". E, através do coral, elaborar uma metáfora de um povo unido, coeso, "embalado" pelos mesmos ideais patrióticos e cívicos...

\section{6. "Música pura" / Música de programa"?}

No Ensaio e nos diversos artigos publicados por Mário de Andrade em jornais e revistas durante a década de 30 e inícios dos anos 40, a música de programa ou descritiva sempre foi muito criticada. Por esse motivo, Mário não admitia a simples transcrição de temas folclóricos nas músicas escritas pelos modernistas. 
Inspirando-se nas teorias formalistas, sempre defendeu a chamada Arte Pura ${ }^{108}$. Esta não deveria possuir outro significado do que os seus próprios signos sonoros (significantes, exclusivamente). E, para justificar o seu projeto modernista, Mário de Andrade resgatou a música clássica do Antigo Regime (século XVIII) como um "modelo" a ser adaptado pelos compositores conforme os novos tempos nacionalistas: "... o período clássico é o período mais fecundo em compositores menores, espanta a riqueza excepcional de qualidades musicais desses autores. O século XVIII é um tempo em que todo mundo escrevia bem..." 109 .

\section{Coda}

O Ensaio sobre a música brasileira, escrito por Mário de Andrade em 1928, sintetizou os principais anseios de compositores, intelectuais, intérpretes preocupados com a nacionalização da música erudita no Brasil.

Este Manifesto ou Segunda Carta sobre o novo descobrimento do País representou, de um lado, uma espécie de contradiscurso agressivo e virulento em face da "presença" dominante de um gosto artístico herdado da Belle Époque Tropical, internalizado pelas elites burguesas neodarwinistas e republicanas durante os anos 20, nas cidades do Rio de Janeiro e São Paulo, em especial; e, de outro, um grito de alerta capaz de envolver, emotiva, ideológica e esteticamente, o artista-criador em prol da pesquisa da música popular - "povo inculto"- como fonte de "inspiração" de suas obras, numa fase de construção ou primitivista atrelada a um determinado conceito de atraso. A partir desse marco zero, o artista deveria envolver-se com esse imaginário, de matizes folclóricos e rurais, visando criar, futuramente, o "rosto ou retrato musical" de uma Nação chamada Brasil... 


\section{NOTAS}

1. Renato ALMEIDA, "A volta à música pura", in Revista do Brasil, Rio de Janeiro, XCIX:224-6, mar. 1924.

IDEM, "A traição da música popular", in WECO, Rio de Janeiro, V-VI:68, jun./jul. 1930 .

Mário de ANDRADE, "Música brasileira", in Correio Musical Brasileiro, São Paulo, 4:5-6, 15/7/1921.

Ronald CARVALHO, "A música de Villa-Lobos", in O Estado de S. Paulo, $17 / 2 / 1922$.

Luciano GALLET, "Reagir", in WECO, Rio de Janeiro, II:3-5, mar. 1930. Fabiano LOZANO," O canto nas escolas primárias de São Paulo", Boletim Latino Americano de Música, Lima, II:411-6, 1936.

2. Ludwig LUERHASS JR., Getúlio Vargas e o triunfo do nacionalismo brasileiro. Estudo do advento da geração nacionalista de 1930, Belo Horizonte: Itatiaia; São Paulo: EDUSP, 1986, p. 63.

3. Id., ibidem, p. 66.

4. " $\ldots$ assim, o herói romântico de Alencar, Peri, foi desbancado pelo Jeca Tatu de Monteiro Lobato, figura satírica, mas neo-realista, de uma vítima da sociedade, que passou a ser a imagem do brasilei ro rural - representando a verdadeira decadência moral e material das massas. (...) o nacionalismo de Lobato visava, criando aquele estereótipo, a convencer um círculo mais largo de brasileiros que a sua pátria era um País enfermo, precisadíssimo de tratamento". Cf. L. LUERHASS, op. cit., p. 54.

5. Alguns dos intelectuais do grupo "Antropofagia" abandonaram o culto esotérico do homem natural e passaram a discutir os problemas sociais com maior realismo literário e artístico. Outros, levados pelas suas preocupações com a vida dos homens pobres e excluídos sociais, engajaramse nos partidos de esquerda.

6. O Grupo Verde-Amarelo preocupou-se com os problemas ligados à educação nacionalista dos brasileiros, conforme uma leitura da "História do Brasil". Devido à apologia do pragmatismo e da ação, muitos desses intelectuais engajaram-se nos movimentos políticos conservadores de matizes integralistas ou fascistas.

7. Paulo PRADO, Retrato do Brasil. Ensaio sobre a tristeza brasileira, $4 .^{a}$ ed., Rio de Janeiro, 1933.

Alberto TORRES, O problema nacional; introdução a um programa de organização nacional, Rio de Janeiro, Imprensa Nacional, 1914.

8. Mário de ANDRADE, "Marcelo Tupinambá", in Música, doce música, São Paulo, Martins Fontes, 1963, p. 115.

9. Antônio CÂNDIDO, "Uma palavra instável", in Folha de S. Paulo, Livros, Caderno 5, 27/8/1995, p. 13. 
10. Jeffrey D. NEEDELL, Belle Époque Tropical, São Paulo, Companhia das Lctras, 1993, p. 58-61.

11. IDEM, ibidem, p. 67.

12. Id., ib., loc. cit.

13. Idem, p. 71-2.

14. Iraci Galvão SALLES, República: a Civilização dos excluidos (Representações do "trabalhador nacional". 1870-1919), São Paulo, 1995, p. 71-2, Tese (Doutorado), FFLCH-USP.

15. A expressão "canção popular", utilizada por Mário de Andrade, referiase à música folclórica.

16. Mário de ANDRADE, "Música brasileira", in Correio Musical Brasileiro, São Paulo, ano I, 4:5, 15/7/1921.

17. Louis Moreau Gottschalk. Grande Fantasia Triunfal sobre o Hino Nacional Brasileiro. Obra composta para orquestra c banda marcial, incluia o efeito espetacular de salvas de canhão. Essa peça foi proibida pela censura do governo militar em 1973, sendo liberada em 7 de setembro dc 1981. Gottschalk nasceu em New Orleans em 8 de maio de 1829 c faleceu no Rio de Janeiro em 26 de novembro de 1869.

18. Mário de ANDRADE, "Música brasileira", loc. cit..

19. Antônio CÂNDIDO, op. cit., loc. cit..

20. Florestan FERNANDES, "Mário de Andrade c o folclore brasilciro", Revista do Arquivo Municipal, São Paulo, CVI:135-158, jan./fev. 1946. IDEM, "Folclore e Ciências Sociais", in Revista Brasiliense, São Paulo, 24:133-51, JUL./AG. 1959.

21. "Gaúcho" (Corta Jaca). Maxixe de Chiquinha Gonzaga, cscrito para peça "Zizinha Maxixe"; "Odeon"; "Brejeiro"; "Apanhei-ıc cavaquinho"de Ernesto Nazarcth; "Urubu"; "Carinhoso"- Pixinguinha; "Rasga Coração" de Catulo da Paixão Cearense...

22. Darius Milhaud, compositor ligado ao "Grupo dos Scis"; Arthur Rubinstein (pianista, grande divulgador da obra villalobiana no exterior); Vera Janacopulos (cantora e divulgadora, a partir dos anos 20, de canções escritas por Villa-Lobos); Mário de Andrade (pocta, professor de música, folclorista); Renato Almeida (autor da História da Música Brasileira, $\mathrm{cm} 1$ 926. Escreveu diversas obras sobre o folclore brasileiro).

23. Ver: Marísia Costa ABBUD, Mário de Andrade e as manifestações artisticas em São Paulo (1927-30), São Paulo, 1979, Dissertação (Mestrado), ECA-USP;

Jorge COLI, Edição crítica de O Mundo Musical de Mário de Andrade, 2 vol., São Paulo, s.d., Tese (Doutorado), FFLCH-USP.

24. Para Mário de Andrade, "música popularesca" restringia-se a todas as músicas escritas por compositores populares urbanos, em geral, ligados à "indústria do entretenimento". 
25. Mário de ANDRADE, "Camargo Guarnieri", in Música, doce música, op. cit., p. 328.

26. IDEM, "Música nacional", in Música, doce música, op. cit., p. 285.

27. Ibidem, loc. cit..

28. Achille PICCHI, "O Ensaio sobre a música brasileira de Mário de Andrade". Trabalho apresentado junto à disciplina "História: música $\mathrm{c}$ modernidade", por mim ministrada cm nível de Pós-Graduação, cm 1993.

29. Mário de ANDRADE, O Ensaio sobre a música brasileira, São Paulo, Martins Fontes, 1962, p. 19.

30. Ver: Béla BARTOK, Escritos sobre música popular, 3.a ed., México, Siglo Veintiuno, 1985.

31. J.P. RAMEAU, Génération harmonique ou traité de musique théorique et pratique, Paris, 1737

A. SCHOENBERG, Harmonielehre, Viena Universal Ed., 1911.

32. Mário de ANDRADE, "Terminologia musical", in Música, doce música, p. 56-7.

33. Josć Eduardo G. da Silva MARTINS, Henrique Oswald: compositor romântico, 1.0 vol., São Paulo, 1988, Tese (Doutoramento), FFLCH-USP, p. 202-3.

34. "A Grande Luz", in Revista Brasileira de Música, v. IX, Rio de Janeiro, Escola Nacional de Música, 1943.

35. "Mário de Andrade, um esteta musical", in O Estado de S. Paulo, Cultura, $244: 8,17 / 2 / 1985$.

36. "A Música Brasileira Moderna", in Revista da Associação Brasileira de Música, ano I, 1:8, 1932.

37. "Chronica Musical", in Revista do Brasil, 3.a fase, ano III, 8:95, fev. 1939.

38. João CALDEIRA FILHO, Discurso: sessão solene para a entrega do prêmio ao Macstro Camargo Guarnieri, in Resenha Musical, Araraquara, ano VI, n.os 71 c 72, 1944, p. 10.

39. Mário de ANDRADE, Pequena IIistória da Música, 5.a cd., São Paulo, Martins Fontes, 1958, p. 153.

40. Ibidem, p. 155.

41. Ibidem, p. 154.

42. Ibidem, loc. cit..

43. Ibidem, p. 155.

44. Ibidem, p. 155.

45. Ibidem, p. 156.

46. Ibidem, p. 158.

47. Ibidem, p. 159.

48. Ibidem, p. 159.

49. Ibidem, p. 161. 
50. Ibidem, p. 162.

51. Ibidem, p. 168.

52. Ibidem, p. 168.

53. Ibidem, p. 178.

54. Ibidem, p. 179.

55. Mário de ANDRADE, "Ernesto Nazareth", in Música, doce música, p. 130 .

56. IDEM, "Tculos mas músicos", in Mísica, doce música, p. 318.

57. IDEM, "Evolıção social da música brasileira", in Aspectos da Música Brasileira, 2.a cd., São Paulo, Martins Fontes, 1975, p. 16.

58. IDEM, O Ensaio..., p. 16.

59. Ibidem, p. 18-9.

60. IDEM, "Marcelo Tupinambá”, in Música, doce música, p. 120.

61. IDEM, "Campanha contra as temporadas líricas", VI, in Música, doce música, p. 202-3.

62. Grifo nosso.

63. Mário de ANDRADE, O Ensaio..., p. 20.

64. Ibidem, p. 19.

65. IDEM, "XIV Socicdade de Conccrtos Sinfônicos", in Música, doce música, p. 246.

66. IDEM, O Ensaio..., p. 15-6.

67. Ibidem, p. 14.

68. Grifo nosso.

69. Mário de ANDRADE, O Ensaio..., p. 14.

70. Ibidem, p. 14.

71. IDEM, "Lourenço Fernandez", in Diário Nacional, São Paulo, 21/7/1928, p. 7.

72. IDEM, "Música nacional", in Música, doce música, p. 284-6.

73. IDEM, "Música nacional", in O Estado de S. Paulo, 12/2/1939, p. 1.

74. IDEM, O Ensaio..., p. 19.

75. Grifo nosso.

76. Mário de ANDRADE, O Ensaio..., p. 26.

77. IDEM, Evolução social da música brasileira, p. 28-9.

78. "Situando-se em relação à questão do 'nacionalismo musical', o compositor Santista - cuja militância de esquerda ć referida como um dos traços de sua formação - já nos havia dado seu testemunho (c tomado posição quanto aos efeitos traumáticos, no ambiente musical brasileiro, das idéias de Zdanov)." Cr. Haroldo de CAMPOS, "As Epifanias de Gilberto Mendes", in Gilberto MENDES, Uma Odisséia Musical, Prefácio, São Paulo, EDUSP/Giordano, 1994, p. XII.

79. Grifo nosso.

80. Grifo nosso. 
81. Mário de ANDRADE, O Ensaio..., p. 17.

82. Ver Jean-Michel PALMIER, Weimar en Exil, Paris, Payot, 1988, 2 vols.

83. Mário de ANDRADE, O Ensaio..., p. 18.

84. A lição do amigo. Cartas de Mário de Andrade a Carlos Drummond de Andrade. Rio de Janciro, José Olympio, 1982, p. 156.

85. Nicolau SEVCENKO, Orfeu Extático na Metrópole. São Paulo: sociedade e cultura nos frementes anos 20 , São Paulo, Companhia das Letras, 1992.

86. Orlando de BARROS, Custódio Mesquita, um compositor romântico. O entrelenimento, a canção sentimental c a política no tempo de Vargas (1930-1945), vol. I, São Paulo, 1995, Tese (Doulorado), FFLCH-USP, p. 295.

87. Mário de ANDRADE, "Dinamogenias políticas", in Música, doce música, p. 104-5; 111.

88. IDEM, O Banquete, São Paulo, Duas Cidades, 1977, p. 45.

89. Ibidem, p. 29.

90. "A música brasileira", in Cultura Musical, Rio de Janeiro, 2:1, set. 1930.

91. Andrade MURICY, "A música brasileira moderna", in Correio da Manhã, Rio de Janeiro, 18/12/1931.

92. Ibidem, loc. cit..

93. Mário distinguia a música conforme três "níveis": 1.o) folclórica ou popular; 2.0) popularesca; 3.0) crudita.

94. Florestan FERNANDES, "A situação musical no Brasil", in Ariel, Revista de Cultura Musical, São Paulo, 9:318, jun. 1924.

95. Mário de ANDRADE, Modinhas Imperiais, 3.a cd., Belo Horizontc, Itatiaia, 1980, p. 1.

96. IDEM, "Lundu do escravo", in Muisica, doce música, p. 79-80.

97. Lúcio RANGEL, Sambistas \& Chorões, São Paulo, Martins Fontes, 1962, p. 22-23.

98. Mário de ANDRADE, "Carnaval", in Diário Nacional, São Paulo, 19/ $2 / 1928$, p. 7.

99. Turunas da Mauricéia. Conjunto vocal $\mathrm{c}$ instrumental organizado $\mathrm{cm}$ 1926 no Recife (PE) e constituído por Luperce Miranda, Manuel de Lima, Augusto Calheiros, Romualdo Miranda, entre outros. No Rio de Janciro cantaram cocos, emboladas, ritmos pouco conhecidos pelos cariocas. Em 1927 gravaram Helena (Luperce Miranda) e Pinião, cmbolada de autoria de Augusto Calheiros e Luperce Miranda, tornandose o grande sucesso do Carnaval de 1928.

100. Mário de ANDRADE, O Ensaio..., p. 22.

101. Ibidem, p. 23.

102. Ibidem, p. 26.

103. Ibidem, p. 49-50. 
104. Ibidem, p. 53.

105. Ibidem, p. 67.

106. Grifo nosso.

107. Mário de ANDRADE, O Ensaio..., p. 64-6.

108. Enrico FUBINI, "El formalismo cn el siglo XX", in La estética musical desde la Antigüedad hasta el siglo XX, Madrid, Alianza Ed., 1988, p. 345-371.

109. Mário de ANDRADE, Pequena História da Música, São Paulo, Martins Fontes, 1958, p. 110.

Arnaldo Daraya Contier é professor de História da Cultura e História Contemporânea da Universidade de São Paulo. 